\title{
Scenario-Based Active Learning in a Low-Tech Environment
}

\author{
Candice C. Dahl
}

ABSTRACT. While it can be a challenge to facilitate meaningful and effective student learning in a low-tech environment, the SMART Start Library orientation program for new undergraduates at Brock University accomplished just that. After describing the program and its goals, as well as the facilities available at the library in 2002 when the program was first implemented, this paper explains how an interactive, scenario-based approach to learning was employed, even though very limited technology was available in the library's instruction room.

Finally, student responses to the type of instruction they received are shared.

KEYWORDS. Active learning, library instruction, library orientation, scenario-based learning

Candice C. Dahl, BA (Hon.), MA, MISt, is Reference/Instruction Librarian, James A. Gibson Library, Brock University, St. Catharines, Ontario (address e-mail to: cddahl@sprint.ca).

Published in:

College \& Undergraduate Libraries, Vol. 11(2) 2004

http://www.haworthpress.com/web/CUL

2004 by The Haworth Press, Inc. All rights reserved.

Digital Object Identifier: 10.1300/J106v11n02_02 
Although many academic libraries now have some sort of electronic classroom in which to carry out instruction, such facilities are by no means universal. Furthermore, even in library classrooms that do contain technology for teaching, the type of equipment available varies greatly. While some classrooms are wireless and fully equipped with numerous laptops, multiple projectors and screens, video/DVD capabilities, and more, others are more modestly furnished with an instructor's workstation, one Internet connection, and a single data projector. Regardless of the technology available it is always possible to create some type of interactive, and even hands-on, learning experience for students. Effective face-to-face instruction in low-tech environments, and even in high-tech ones, depends to some extent on the creativity of the lesson planners and their readiness to incorporate a scenario-based design, active learning, or other such strategies.

The determination to employ these strategies effectively in a low-tech environment formed the basis of lesson planning for SMART Start Library, an orientation program for first-year students at the James A. Gibson Library, Brock University, St. Catharines, Ontario. After describing the program and its goals, as well as the facilities available at the library in 2002 when the program was first implemented, this paper explains how an interactive, scenario-based approach to learning was employed. Finally, student responses to the type of instruction they received are shared.

Much of the recent literature about library orientation programs focuses on either the development of semester-long University Life or Information Literacy credit courses (Blakeslee 1998; Jacobs 2001; Sugarman and Mosby 2002; Malone and Videon 2003) or on the integration of information literacy concepts into foundational subject-specific courses (Brown and Krumholz 2002; Rockman 2003). Although less has been written about library tours, which provide only the most basic introduction to resources and services, they are still commonly offered orientation activities. Oling and Mach (2002) determined that the "old fashioned guided tour" is still the most popular among ARL institutions. However, some libraries are experimenting with enriched and interactive tours (Walton et al. 2001), as well as web-based virtual tours.

Situated in between these two approaches to orientation are the 50-90 minute general orientation sessions, not necessarily associated with a 
specific class, that allow for interaction between librarians and students and facilitate hands-on learning. This is the model for SMART Start Library. One example of this design is the orientation program offered for freshmen engineering students at the University of Maryland (Arnold, Kackley, and Fortune 2003), where librarians combine a brief instructor-led orientation with hands-on activities for students. Macklin (2002) also describes a 50-minute orientation program for incoming freshmen, which incorporates problem-based learning. The interactive tours described by Walton et al. (2001) are also similar, as students participate in a two-hour long open house which is related to the first-year curriculum and based on the principle of active learning.

Although a variety of delivery methods and teaching techniques are employed in different programs, the importance of a personal approach, where librarians and students meet, is repeatedly being demonstrated (Churkovich and Oughtred 2002; Van Scoyoc 2003). Another important component of orientation activities, regardless of their length or the breadth of their goals, is active learning. Many have shown the effectiveness of this technique (Allen 1995; D'Angelo 2001; Frantz 2002; Macklin 2002) and numerous compilations of active learning strategies and activities are available (Gradowski, Snavely, and Dempsey 1998; Jacobson and Gatti 2001; Nims and Andrew 2002).

While orientation activities for first year students can last for under an hour or up to a whole term, the literature suggests that face-to-face instruction that incorporates a hands-on and active approach to learning is both effective and well-received by students. It is on these principles that SMART Start Library is based.

SMART Start Library is a 50-minute orientation session for students entering university directly after secondary school. Just as new students benefit from a formal introduction to their chosen university and its policies, services, and physical layout, students need a similar introduction to their new library. SMART Start sessions are intended to be informative, yet informal and interactive, and the objectives are to introduce students to library services and the library's overall layout, teach students where to get help, and equip them to find basic resources. Students attend voluntarily and on their own time, so it is 
especially important to ensure their satisfaction with the format as well as the content.

Between 25 and 30 sessions are offered every September. We schedule three sessions per weekday for approximately two weeks and there is a maximum of 25 students in each. The program is promoted in University mailings, at a day-long University-sponsored orientation for new students during the summer months, and on the library's web site. Through these channels students are given the URL of the SMART Start Library registration page and are asked to register with their student ID and e-mail address. This allows the library to send reminders to students two days before the session for which they have registered. Registration begins in July but students may register right up until the time a session starts as long as the session is not full. Often students attend without having registered at all.

The challenge faced in the planning stages of SMART Start Library was how to meet our goal of interactivity given the limitations of the library's instruction room at that time. The room we use seats no more than 30 comfortably and there are no tables or desks. There is an instructor's workstation with an Internet connection, and it is connected to a data projector. The projection screen is at the front of the room and there are no whiteboards. Although there was a time when even this type of equipment was cutting-edge, this setup can now be safely described as low-tech. The possibilities for hands-on practice and collaborative work appeared limited during the early stages of planning. However, keeping the session objectives in mind, we devised ways to overcome these barriers and to satisfy students as well.

Each SMART Start Library session begins with a short introduction to the library's homepage, which is used as a springboard to discuss the services and policies most relevant to students. Because students do not have computers themselves they cannot explore the pages on their own, so we provide them with a paper handout that labels and describes each of the major sections of the Web site accessible from our home page (see Appendix 1). They learn how to find items on reserve, where our help pages are, and how to set up their library accounts. These details are communicated through a brief, instructorled demonstration. 
The bulk of the session, however, is spent on finding resources to answer a mock essay question (see Appendix 2). Students are not required to actually answer the question on the worksheet, but only to locate a book or journal that they would use if the assignment were real. This activity provides students with the opportunity to engage in a collaborative, active approach to solve the problem of how and where to find library resources. Essentially, students are given a trial run at locating basic resources, which is something they are required to do for numerous class assignments throughout the year. In order to keep this part of the session manageable it is important to create an essay question about which it is easy to find some information, but not too much. A question about reality television works well at our institution since many students are familiar with reality shows, and resources are readily available thanks to the institution's Popular Culture program.

In order to locate the necessary resources about reality shows in North America, students divide themselves into groups of 3-5. Using the handout of the homepage, they determine whether to begin their search in the library catalog or in the databases. Each group elects a spokesperson who may be called upon to conduct a basic search in front of the class with the guidance of his or her group. When a group is selected to demonstrate a search the spokesperson is invited up to the instructor's workstation. Throughout the search the group has to make several decisions: whether to go to the library catalog or a database, to use a keyword or a subject search, and what specific keywords or subject headings to use. The other groups observe and compare their strategies. The group setting provides students with support and security, while the public demonstration allows students to learn from each other and creates a forum for the session leader to provide tips and guidance on searching. Because of time constraints only one group demonstrates a book search and a second group demonstrates a journal search. When the class selects a suitable item from the results list, students determine what information they need to locate the item in the library and all of them record this on their worksheets. This provides the instructor with an opportunity to talk about Library of Congress call numbers and journal citations.

In the last few minutes of the session students are sent into the stacks to locate either the book or the journal article discovered in their public searches. They are asked not to bring the items back with them, as several groups look for the same items every day for a period of two 
weeks. In order for the instructor to be certain that students find the book in question, and in case a sought-after book happens to be signed out, colored book dummies are placed beside all of the books that usually appear in the results list of the catalog search. Students are asked to record the color of the dummy on their worksheet. When they return to the instruction room, students report what they found and discuss any problems that were encountered. This final activity allows students to learn the physical layout of the library, as they are required to use the elevators, visit one of the upper floors, interpret directional signs and, finally, use a Library of Congress call number.

In the two years that the SMART Start Library program has been offered, over 800 students have participated and filled in evaluation forms (see Appendix 3). In 2002, $78 \%$ of students either agreed or strongly agreed that it was valuable to participate in the program and 93\% either agreed or strongly agreed that they learned something. Many also indicated that they liked the informal nature of the session and that they would recommend the program to other students. An open-ended question on the evaluation sheet allows students to identify or comment on the most useful part of the session. While some express a desire for every participant to have access to his or her own computer, many indicate that the best part is doing an actual search together and going into the stacks to locate materials. Even in the first two weeks of September, before they have specific research needs, the students recognize that having the ability to identify and locate materials is important. Taking a scenario-based approach to this learning experience by setting it in the context of a mock assignment that is similar to those required in actual classes allows them to see how their trial run at doing library research is entirely related to the research they will do later on.

Library staff members fully recognize that what we can provide students with in SMART Start Library is just that: a smart start, but certainly not a highly developed set of research skills. The program allows us to establish contact with these students in a positive environment, provide them with some very basic skills and, hopefully, the confidence to ask for help when necessary. The overall reaction of students to SMART Start Library has been positive. Their responses to set questions, as well as their general comments on the evaluation sheets indicate that even in a low-tech environment, active and even hands- 
on learning can be successful and is, in fact, extremely valuable to them.

Although more and more academic libraries are renovating or building new classrooms that are equipped with full suites of teaching technologies, not all institutions are in a position to do so. Our experience at the James A. Gibson Library, however, suggests that a welldesigned program can make up for certain technological shortcomings. Our orientation program incorporates a scenario-based approach to learning basic research skills in order to actively engage students and make it clear that the skills they acquire in SMART Start Library are the ones they will need to do research for assignments throughout the year. Group work, student demonstrations, and the resource hunt in the stacks ensure their active participation throughout the session, and student comments indicate that the practice they get searching and locating resources are the best parts. While designing a lesson plan to fit the teaching facilities that are available can be a challenge, it is not always necessary to change one's overall objectives. Sometimes what is required is finding creative ways of meeting those objectives.

\section{QUICK BIB}

Arnold, Julie, Robert Kackley, and Stephen Fortune. 2003. "Hands-on Learning for Freshman Engineering Students." Issues in Science and Technology Librarianship 37 [online journal]. Retrieved April 13, 2004. <http://www.istl. org/03-spring/article3.html>.

Frantz, Paul. 2002. "A Scenario-based Approach to Credit Course Instruction." Reference Services Review 30 (1): 37-42.

Macklin, Alexius Smith. 2002. "Going to the Library? You're Virtually There: Problem-Based Learning for a 50-Minute Orientation." In First Impressions, Lasting Impact: Introducing the First-Year Student to the Academic Library, edited by Julia K. Nims and Ann Andrew, 101-104. Ann Arbor: Pierian Press.

Walton, Linda, Teresa Westphal, Brian Lauer, Kurt Munson, and James Shedlock. 2001. "No More Tours: How Library Tours of the Past Become Today's Celebrations." Medical Reference Services Quarterly 20 (1): 39-48. 


\section{REFERENCES}

Allen, Eileen E. 1995. "Active Learning and Teaching: Improving Postsecondary Library Instruction." The Reference Librarian 51/52: 89-103.

Arnold, Julie, Robert Kackley, and Stephen Fortune. 2003. "Hands-on Learning for Freshman Engineering Students." Issues in Science and Technology Librarianship 37 [online journal]. Retrieved April 13, 2004. <http://www.istl.org/03-spring/article3. html>.

Blakeslee, Sarah. 1998. "Librarian in a Strange Land: Teaching a Freshman Orientation Course." Reference Services Review 26 (2): 73-78.

Brown, Cecilia, and Lee R. Krumholz. 2002. "Integrating Information Literacy into the Science Curriculum." College and Research Libraries 63(2): 111-23.

Churkovich, Marion, and Christine Oughtred. 2002. "Can an Online Tutorial Pass the Test for Library Instruction? An Evaluation and Comparison of Library Skills Instruction Methods for First Year Students at Deakin University." Australian Academic and Research Libraries 33(1): 25-38.

D'Angelo, Barbara J. 2001. "Using Source Analysis to Promote Critical Thinking." Research Strategies 18 (4): 303-09.

Frantz, Paul. 2002. "A Scenario-based Approach to Credit Course Instruction." Reference Services Review 30 (1): 37-42.

Gradowski, Gail, Loanne Snavely, and Paula Dempsey, eds. 1998. Designs for Active Learning: A Sourcebook of Classroom Strategies for Information Education. Chicago: Association of College \& Research Libraries.

Jacobs, Mark. 2001. "Speakeasy Studio and Café: Information Literacy, Web-Based Library Instruction, and Technology." Information Technology and Libraries 20 (2): 66-71.

Jacobson, Trudi E. and Timothy H. Gatti. 2001. Teaching Information Literacy Concepts: Activities and Frameworks from the Field. Pittsburgh: Library Instruction Publications.

Macklin, Alexius Smith. 2002. "Going to the Library? You're Virtually There: Problem-Based Learning for a 50-Minute Orientation." In First Impressions, Lasting Impact: Introducing the First-Year Student to the Academic Library, edited by Julia K. Nims and Ann Andrew, 101-104. Ann Arbor: Pierian Press. 
Malone, Debbie, and Carol Videon, eds. 2003. First Year Student Library Instruction Programs, CLIP Note \#33. Chicago: American Library Association.

Nims, Julia K., and Ann Andrew, eds. 2002. First Impressions, Lasting Impact: Introducing the First-Year Student to the Academic Library. Papers Presented at the Twenty-Eighth National LOEX Library Instruction Conference. Ann Arbor: Pierian Press.

Oling, Lori, and Michelle Mach. 2002. "Tour Trends in Academic ARL Libraries." College and Research Libraries 63 (1): 13-23.

Rockman, Ilene F. 2003. "Integrating Information Literacy into the Learning Outcomes of Academic Disciplines: A Critical 21st Century Issue." College and Research Libraries News 64 (9): 61215.

Sugarman, Tammy, and Anne Page Mosby. 2002. "Making a Weak Link Stronger: Incorporating Information Literacy into a SemesterLong Freshman Seminar." Georiga Library Quarterly 39 (2): 12-16.

Van Scoyoc, Anna M. 2003. "Reducing Library Anxiety in First-Year Students: The Impact of Computer-Assisted Instruction and Bibliographic Instruction." Reference \& User Services Quarterly 42 (4): 329-41.

Walton, Linda, Teresa Westphal, Brian Lauer, Kurt Munson, and James Shedlock. 2001. "No More Tours: How Library Tours of the Past Become Today's Celebrations." Medical Reference Services Quarterly 20 (1): 39-48. 
APPENDIX 1. Handout of the Library's Home Page

SMART Start Library 2003

\begin{tabular}{|ll|}
\hline Use this to find: & $\begin{array}{l}\text { reserve items } \\
\text { books } \\
\text { journals (if you already know the title }\end{array}$ \\
Also, click here to set up MY LIBRARY ACCOUNT
\end{tabular}

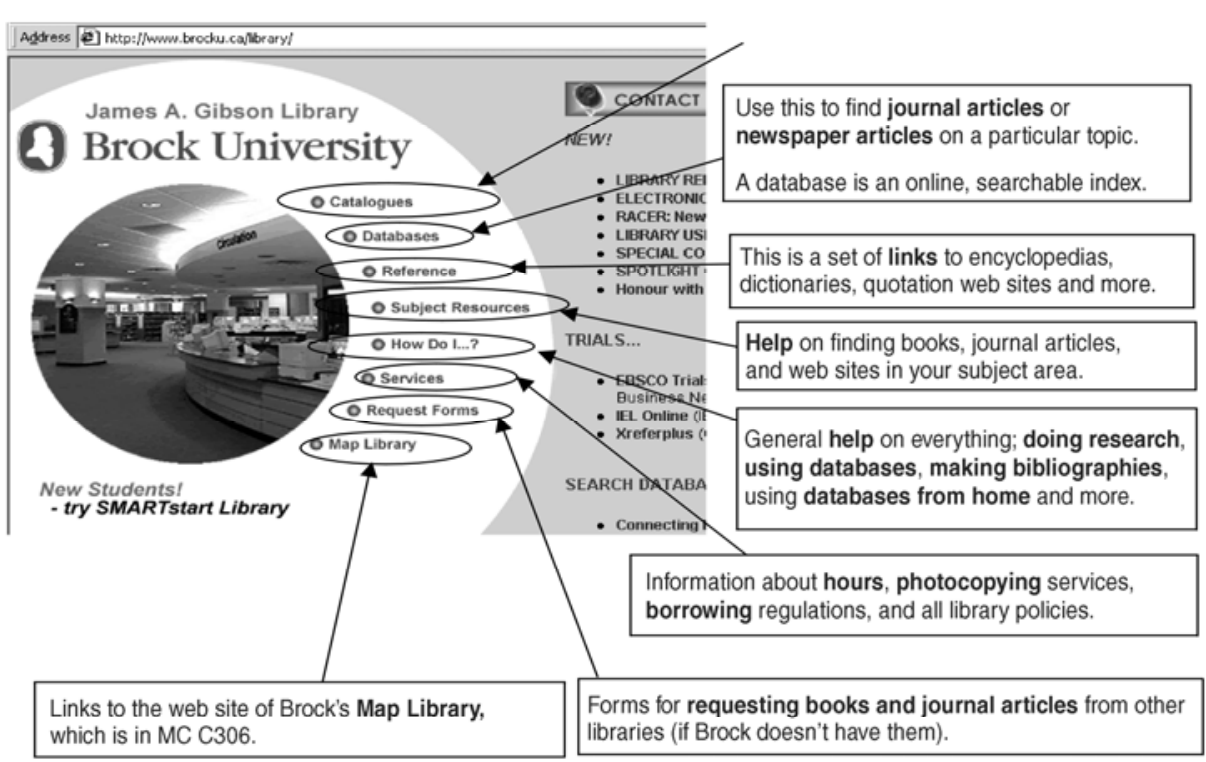




\section{APPENDIX 2. Assignment Worksheet \\ SMART Start Library \\ Fall, 2003 \\ ST 211, Library Instruction Room}

Class: Getting by at University 1F90

Instructor: various librarians

Assignment due date: at the end of this class

Assignment 1:

You must find a book and a journal article that will help you understand the rise and/or appeal of reality television in North America.

Locate each item, either upstairs in the library or online.

Please DO NOT remove items from the shelves upstairs, as other groups of students may be looking for the same items. Instead, note the color of the item (or the book dummy beside it) and leave it in its place.

\section{Book}

Title:

Call number and floor:

Color:

\section{Journal Article}

Article Title:

Journal Title:

Volume, issue, date and page numbers:

Call number and floor (if it isn't online):

Color: 


\section{APPENDIX 3. Evaluation Form}

\section{SMART Start Library Student Evaluation 2003}

Please complete this evaluation form so that we know what changes should be made to SMART Start Library

\begin{tabular}{|l|l|l|l|l|l|}
\hline & $\begin{array}{l}\text { Strongly } \\
\text { Disagree }\end{array}$ & Disagree & $\begin{array}{l}\text { Neutral/ } \\
\text { Undecided }\end{array}$ & Agree & $\begin{array}{l}\text { Strongly } \\
\text { Agree }\end{array}$ \\
\hline The session was informal & & & & & \\
\hline $\begin{array}{l}\text { I would have liked the session to } \\
\text { be more formal }\end{array}$ & & & & & \\
\hline I learned something today & & & & & \\
\hline $\begin{array}{l}\text { The session met my } \\
\text { expectations }\end{array}$ & & & & & \\
\hline $\begin{array}{l}\text { I think it was valuable to } \\
\text { participate in this program }\end{array}$ & & & & & \\
\hline $\begin{array}{l}\text { I would recommend this } \\
\text { program to other students }\end{array}$ & & & & & \\
\hline $\begin{array}{l}\text { I'll be ready to start using the } \\
\text { library when the time comes }\end{array}$ & & & & & \\
\hline $\begin{array}{l}\text { This was a good time to take } \\
\text { this session }\end{array}$ & & & & & \\
\hline It was easy to register & & & & & \\
\hline $\begin{array}{l}\text { The SMART Start orientation } \\
\text { leaders influenced my decision } \\
\text { to attend }\end{array}$ & & & & & \\
\hline
\end{tabular}

What was the best thing about this session? [Use back if necessary]

What could have been done to make this session better? [Use back if necessary] 